\title{
Computer analysis of routine pathology work schedules using a simulation programme
}

\author{
M. E. CARRUTHERS
}

From the Courtauld Institute of Biochemistry, Middlesex Hospital Medical School, London

SYNOPSIS A simulation progiamme is described which compares the efficiency of laboratory $\stackrel{\circ}{\square}$ work schedules. The number of days' delay on a sample of request forms submitted to a routine $\vec{\rightarrow}$ biochemistry laboratory has been calculated for each of three schedules. Analysis of the results indicated that this method of comparing existing and potential work routines is likely to lead to a significant acceleration in the return of pathology results to the clinician.

The primary aim of routine pathology laboratories is to return accurate results to the clinician as rapidly as possible. In biochemistry and haematology, accuracy and reproducibility have been considerably improved, both by automation and, more recently, by the application of computers to quality control (Whitby, Mitchell, and Moss, 1967; College of Path- ologists, 1969; Whitehead, Becker, and Peters, 1968). Faced by practically static financial resources and a geometrically expanding work $\underset{\complement}{\varnothing}$ load, most laboratories are experiencing in- $\overrightarrow{\vec{P}}$ creasing difficulty in maintaining a sufficiently $\frac{\circ}{3}$ rapid turnover of work. If the return of reports is delayed, the time required for diagnosis Received for publication 21 August 1969.

\begin{tabular}{|c|c|c|c|c|c|c|c|c|}
\hline Schedule & & $\begin{array}{l}\text { Electrolytes } \\
\text { and Glucose } \\
\left(C \mathrm{O}_{2} N A, K \text {, }\right. \\
G L, U)\end{array}$ & $\begin{array}{l}\text { Bone } \\
\left(C A, P O_{4},\right. \\
A L)\end{array}$ & $\begin{array}{l}\text { Bilirubin } \\
\text { and } \\
(P T, O T\end{array}$ & $\begin{array}{l}\text { in Enzymes } \\
T, L D H)\end{array}$ & $\begin{array}{l}\text { Protein } \\
(T P, A, G, \\
\text { Strip })\end{array}$ & $\begin{array}{l}\text { Circulation } \\
\text { (Chol, UA, } \\
\text { Creat) }\end{array}$ & $\begin{array}{l}\text { Trace } \\
(F E, I B C, P B I)\end{array}$ \\
\hline 1 (Existing) & $\begin{array}{l}\text { Mon } \\
\text { Tues } \\
\text { Wed } \\
\text { Thur } \\
\text { Fri } \\
\text { Sat } \\
\text { Sun }\end{array}$ & $\begin{array}{c}11.00 \\
11.00 \\
11.00 \\
11.00 \\
11.00 \\
10.30 \\
-\end{array}$ & $\begin{array}{l}9.00 \\
\overline{9} .00 \\
\overline{9} .00 \\
= \\
-\end{array}$ & $\begin{array}{l}10 \cdot 30 \\
10 \cdot 30 \\
10 \cdot 30 \\
10 \cdot 30 \\
10 \cdot 30 \\
-\end{array}$ & $\begin{array}{l}9.00 \\
9.00 \\
9.00 \\
9.00 \\
9.00\end{array}$ & $\begin{array}{l}9 \cdot 00 \\
\overline{9} \cdot 00 \\
\overline{9} .00 \\
=\end{array}$ & $\begin{array}{l}\bar{Z} \\
\overline{9} \cdot 00 \\
\bar{Z} \\
\overline{-}\end{array}$ & $\begin{array}{l}\overline{-} \\
\overline{9} \cdot 00 \\
\bar{Z} \\
=\end{array}$ \\
\hline $\begin{array}{l}2 \\
\text { (Alternative) }\end{array}$ & $\begin{array}{l}\text { Mon } \\
\text { Tues } \\
\text { Wed } \\
\text { Thur } \\
\text { Fri } \\
\text { Sat } \\
\text { Sun }\end{array}$ & $\begin{array}{r}2.00 \\
2.00 \\
2.00 \\
2.00 \\
2.00 \\
10.30 \\
-\end{array}$ & $\begin{array}{l}11.00 \\
11.00 \\
11.00 \\
11.00 \\
11.00 \\
10.30 \\
-\end{array}$ & $\begin{array}{l}11.00 \\
11 \cdot 00 \\
11 \cdot 00 \\
11.00 \\
11 \cdot 00 \\
=\end{array}$ & $\begin{array}{l}2.00 \\
2.00 \\
2.00 \\
2.00 \\
2.00 \\
=\end{array}$ & $\begin{array}{l}10 \cdot 45 \\
10 \cdot 45 \\
10 \cdot 45 \\
10 \cdot 45 \\
10 \cdot 45 \\
-\end{array}$ & $\begin{array}{l}\overline{9} .00 \\
\overline{9} .00 \\
\overline{-} \\
\overline{-}\end{array}$ & $\begin{array}{l}\frac{11.00}{11} \cdot 00 \\
\overline{11} \cdot 00 \\
=\end{array}$ \\
\hline $\begin{array}{l}3 \\
\text { (Alternative) }\end{array}$ & $\begin{array}{l}\text { Mon } \\
\text { Tues } \\
\text { Wed } \\
\text { Thur } \\
\text { Fri } \\
\text { Sat } \\
\text { Sun }\end{array}$ & $\begin{array}{r}4.00 \\
4.00 \\
4.00 \\
4.00 \\
4.00 \\
10.45 \\
-\end{array}$ & $\begin{array}{r}4.00 \\
4.00 \\
4.00 \\
4.00 \\
4.00 \\
10.45\end{array}$ & $\begin{array}{l}2.00 \\
3.00 \\
2.00 \\
2.00 \\
2.00 \\
-\end{array}$ & $\begin{array}{l}2.00 \\
2.00 \\
2.00 \\
2.00 \\
2.00 \\
-\end{array}$ & $\begin{array}{l}11 \cdot 00 \\
11 \cdot 00 \\
11 \cdot 00 \\
11 \cdot 00 \\
11 \cdot 00 \\
-\end{array}$ & $\begin{array}{l}\frac{11 \cdot 00}{\overline{11} \cdot 00} \\
\overline{11} \cdot 00 \\
-\end{array}$ & $\begin{array}{l}\frac{11 \cdot 00}{11 \cdot 00} \\
\overline{11} \cdot 00 \\
=\end{array}$ \\
\hline
\end{tabular}




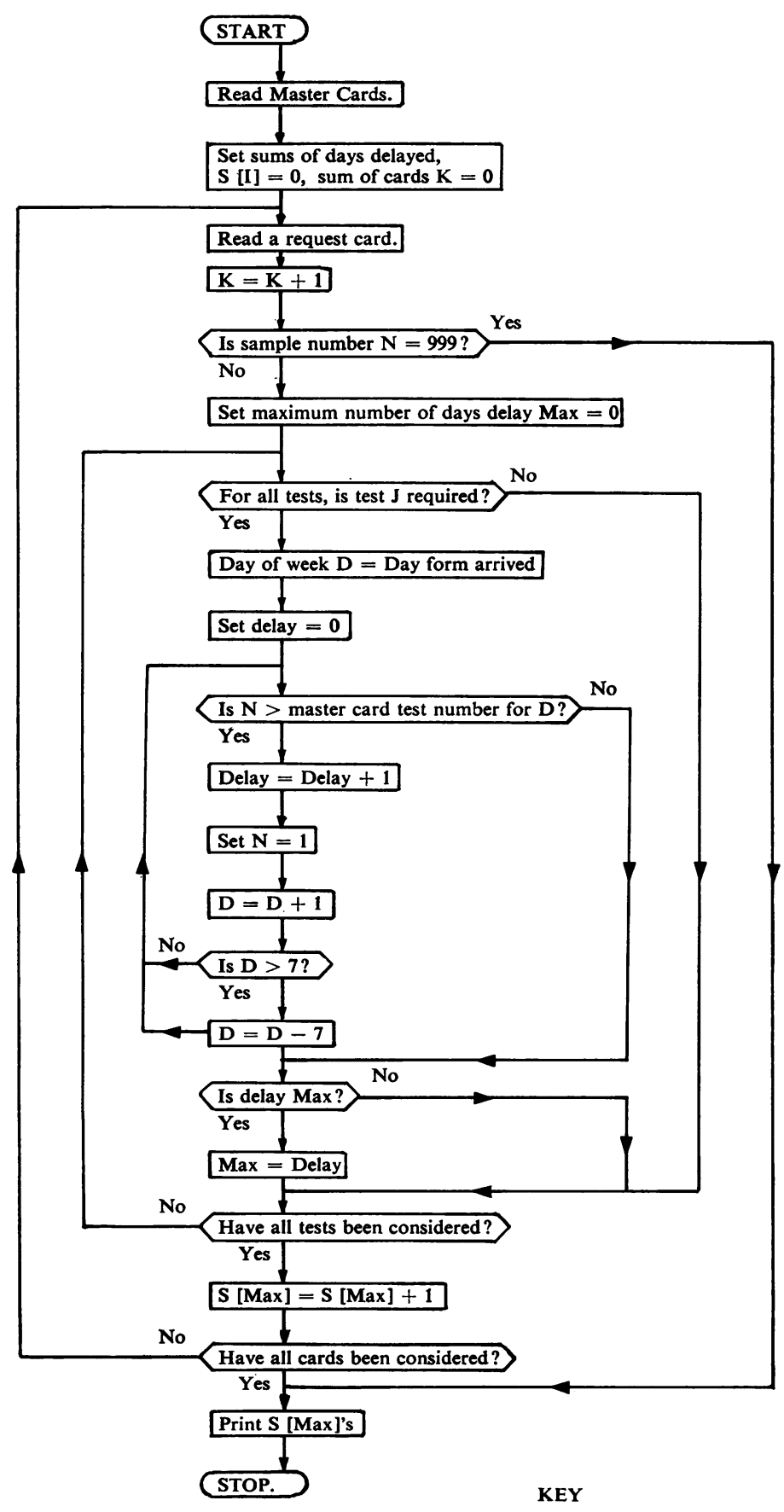

Starting or stopping point

Operation not involving a decision

Operation involving a decision

Indication of direction of flow.

Fig. 1 The programme for applying the laboratory routine which is to be simulated. and treatment is increased, and the expense of ${ }^{c}$ having the patient in hospital and off work rises $\frac{\rho}{5}$. correspondingly.

Little attention has been paid to methods by which computers can assist pathologists in the organization of laboratory work schedules so as to achieve optimal work flow. The effectiveness of any proposed sequence of performingo laboratory tests can be studied by applyingo a work simulation programme to a sample $\bar{c}$ of request forms. Such a programme has been $\Phi_{\alpha}$ designed, allowing a wide variety of potentialo routines to be rapidly evaluated on a quantitatives basis. It was used to compare the efficiency of? the present laboratory timetable with two $\vec{\omega}$ theoretical alternatives (Table). The number of days' delay for each request form was deter $\overline{-0}$. mined for each of these three schedules. The third schedule, though obviously superior to ${ }_{\omega}^{\omega}$ the other two, required considerable expenditure on equipment, while the second did not. The question was whether such expenditure waso justified.

\section{Sampling}

A random sample of completed request formso for biochemical investigations on blood samples was taken on each working day over a periodō of three months. The laboratory numbers ono the forms to be copied each day were selected $\mathbb{Q}^{\circ}$ in advance, and typed out on a weekly sheet $\vec{\circ}$ by a random number programme. Provided with 3 these sheets, the office clerical staff were able? to copy from three to five selected requesto forms in less than 10 minutes. All items of information on the forms, including the results and comments, were copied. Where possible, the original forms were retained and the copies returned to the clinicians.

\section{Coding}

At the end of the three-month collection period all information on the forms was coded and then transferred to IBM punch cards, with one cardw for each form.

As the request forms and specimens had beerf given daily consecutive numbers on reception $\$$ the laboratory number was representative of its time of arrival. It was therefore possible to simulate the laboratory work schedule for a week by putting on master cards, for each $\underset{\mathbb{P}}{\mathbb{P}}$ day and test, the highest laboratory number that a specimen could have and still have particular test performed the same day, eg 8 electrolyte estimations on samples whose lab? oratory number was up to 70 , corresponding to the last sample collected by a porter at 11 年 


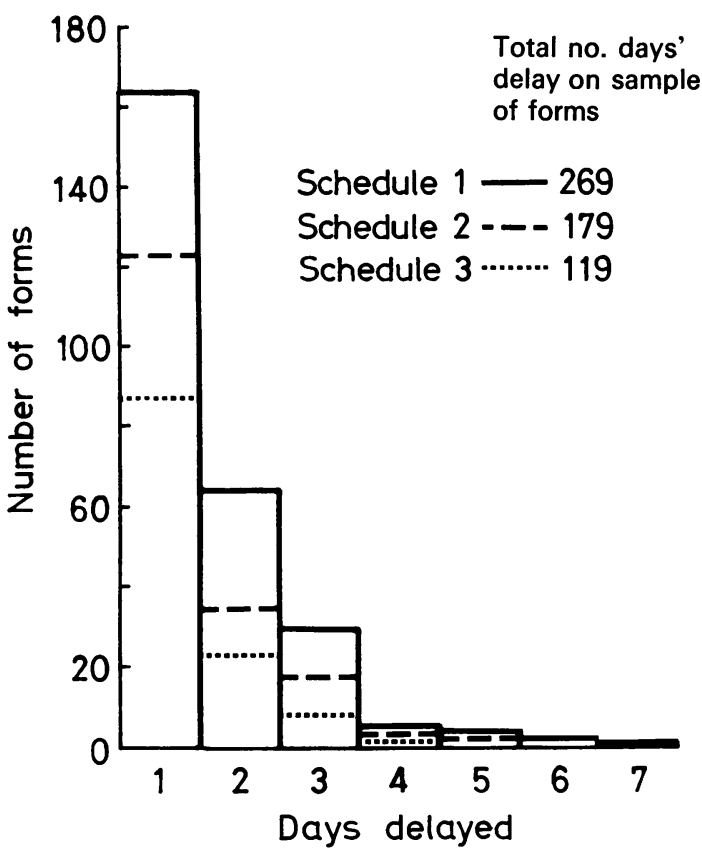

Fig. 2 The result of applying three different laboratory schedules.

o'clock, would be performed the same day. Tests requiring that the sample arrive the previous night, to be done on an early morning run, were represented by the number 2 . Tests not being performed that day were coded as 0 .

\section{The Simulation Programme}

The programme for applying the laboratory routine which is to be simulated is set out in block diagram form in Figure 1. This programme, together with specialized 'card read' and 'print' procedures, were put in algol onto paper tape using a teleprinter. The tape, the 14 master cards, and the request form cards were then processed on the University of London Atlas computer. This gave in its output the number of sample reports that would theoretically be sent back the same day or be delayed from one to seven days.

\section{Results}

The result of applying three different laboratory schedules to this representative sample of the work load is set out in Fig. 2, which shows the daily total of unreturned forms. The continuous line represents the existing routine, and the other two, routines whose effectiveness it was wished to assess.

\section{Discussion}

The figures provided by these simulation pro- $\frac{}{7}$ grammes made it possible to compare quantitatively projected laboratory routines with the present one. It is theoretically possible to design a programme to hunt automatically for an $\stackrel{\vec{s}}{\rightarrow}$ optimal routine. However, there is usually ao limited number of possible alternatives, owing to $\underline{\underline{O}}$ limitation of staff and apparatus. The complexity $\frac{\overline{\bar{c}}}{\overline{\frac{1}{2}}}$ of such a programme, and the number of con- $\stackrel{\Phi}{\varrho}$ straints that would have to be included, make it unlikely that the exercise would be worth while. ${ }_{-}^{\infty}$

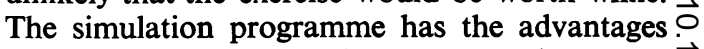
that it is simple, flexible, cheap, and easy to $\vec{\omega}$ apply. Any proposed laboratory routine can $\stackrel{\omega}{\sigma}$ quickly be set out and transferred to master cards. For most laboratories, the results could is be available within 24 hours. This would appear $\omega$ to be preferable to existing trial and error $\dot{\sim}$ methods, which can result in serious disruption 8 of work flow, especially if several successive 은 modifications have to be made in the light of slowly accumulating evidence of a scheme's success or failure.

The benefit which should result from the newer $\vec{\oplus}$ types of multichannel automatic analysers, in terms of more rapid turnover of work, can be predicted more accurately and expressed in terms of cost effectiveness. For example, by changing from routine 1 to routine 2, a total of 90 days' delay could be saved on the sample $\stackrel{Ð}{\varnothing}$ request forms alone. As there were 260 request $\stackrel{\Phi}{2}$ forms in the sample, and 8,673 actual request $\overrightarrow{\vec{O}}$ forms were received during the three months of 3 the study, each sample form represents an average of about 33 requests. Multiplication of the total delay of the sample forms by the number each one represented indicates a possible gain of around 3,000 days over the three-month period. Even if only in $10 \%$ of these cases was a patient's discharge delayed, allowing that each day's stay in hospital costs a minimum of $£ 10$, this would be equivalent to a saving to the hospital of $£ 1,000$ per month. By a similar calculation, routine 3 could save $£ 1,600$ per month, which would soon pay off the cost of the new equipment needed to implement it.

Similar operational research techniques, but applied manually, were used by Weir, Fowler, and Dingwall-Fordyce (1968) for the simulation of surgical admissions. Their study was also directed towards increasing the efficiency of bed utilization by replacing an arbitrary admission system with one based on predictions from accurate data. They conclude that the importance of this type of approach must not be underestimated. It is a way in which innovations can be adequately tested before their introduction.

The information coded on the punch cards is also available for other forms of analysis. These can include the assessment of the relative effectiveness of selective biochemical analyses 
compared with screening procedures. Based on a properly chosen sample, it also gives a detailed picture of the overall pattern of the work load without any need to wait for full annual figures before consequent decisions can be made.

Though in this case the facility which the simulation programme provides for the improvement of the organization of a laboratory timetable has been used in a biochemical context, it should also be applicable to other pathology departments, especially haematology. It is one very positive way in which a pathology department can better the care of both inpatients and outpatients.

I should like to thank Mr Brian Newman, Lecturer in Statistics at the Middlesex Hospital, for an immense amount of help at all stages in this project. My thanks $\subset$ are also due to Professor R. H.S. Thompson, Dr A. L $\varrho$ Miller, and Mr C. Rose, for their valuable advice.

Requests for reprints or copies of the programme should be sent to Dr M. E. Carruthers, Institute of Ophthalmology, Judd- Street, London, WC1 H 9QS.

References

College of Pathologists (1969). Symposium on Automation and Data Processing in Pathology, edited by T. P. Whitehead.D J. clin. Path., Suppl. (Coll. Path.) 3.

Weir, R. D., Fowler, G. B., and Dingwall-Fordyce, I. (1968) The prediction and simulation of surgical admissions. In Computers in the Service of Medicine, vol. 2, edited by $\overrightarrow{0}$ G. MacLachlan and R. A. Shegog, pp. 141-154. OxfordUniversity Press for Nuffield Provincial Hospital Trust, $\vec{\omega}$ London.

Whitby, L. G., Mitchell, F. L., and Noss, D. W. (1967). Quality control in routine clinical chemistry. Advanc. clin. Chem. 10, 65-156.

Whitehead, T. P., Becker, J. F., and Peters, M. (1968). DataC processing in a clinical biochemistry laboratory. In Com- $\omega$ puters in the Service of Medicine, vol. 1, edited by Giv MacLachlan and R. A. Shegog, pp. 113-133. OxfordO University Press for Nuffield Provincial Hospital Trust, London.

\section{Reports and Bulletins prepared by the Association of Clinical Biochemists}

The following reports and bulletins are published by the Association of Clinical Biochemists. They may be obtained from The 0 Administrative Office, Association of Clinical Biochemists, 7 Warwick Court, Holborn, London, W.C.1. The prices include $\vec{F}$ postage, but airmail will be charged extra. Overseas readers should remit by British Postal or Money Order. If this is not possible,, 3 the equivalent of 10 s. is the minimum amount that can be accepted.

\section{SCIENTIFIC REPORTS}

3 Automatic Dispensing Pipettes. An assessment of 35 commercial instruments 1967 P. M. G. BROUGHTON, A. H. GOWENLOCK, G. M. WIDDOWSON, and K. A. AHLQUIST 10s

\section{TECHNICAL BULLETINS}

9 Determination of Urea by AutoAnalyzer November 1966 RUTH M. HASLAM 2s 6d

10 Filter Fluorimeters. A comparative list of 14 instruments March 1967 HANNELORE BRAUNSBERG (Re-issued in response to demand. Text still valuable, list now out of date) $5 \mathrm{~s}$
11 Determination of Serum Albumin by AutoAnalyzer using Bromocresol Green October 1967 B. E. NORTHAM and G. M. WIDDOWSON 2s 6d

12 Control Solutions for Clinical Biochemistry February 1968 P. M. G. BROUGHTON 2s 6d

13 An assessment of the Technicon Type II Sampler Unit March 1968 B. C. GRAY and G. K. MCGOWAN 1s $6 \mathrm{~d}$

14 Atomic Absorption Spectroscopy. An outline of its Principles and a Guide to the Selection of Instruments May 1968 J. B. DAWSON and P. M. G. BROUGHTON 4s
15 A Guide to Automatic Pipettes (2nd edition) June 1968 P. M. G. BROUGHTON 5s

16 A Guide to Automation in Clinical Chemistry May 1969 P. M. G. BROUGHTON 12s $6 \mathrm{~d}(\$ 1.50)$

17 Flame Photometers (2nd edition) 1969 P. WILDING 12s 6d (\$1.50) 